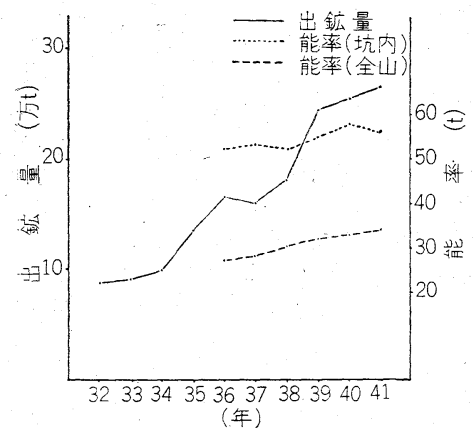

大
泉

\section{Ōizumi Mine}

第 9 表 過去10年間の年間粗鉱量，平均品位拈よび 能率 (坑内, 全山) の推移

\begin{tabular}{|c|c|c|c|c|c|c|}
\hline & \multirow{2}{*}{$\begin{array}{c}\text { 年間出鉱量 } \\
(\mathrm{t})\end{array}$} & 平 & 均 & & \multicolumn{2}{|c|}{$\begin{array}{l}1 \text { 人 } 1 \text { 力月当り } \\
\text { 出鈗 量 }\end{array}$} \\
\hline & & $\mathrm{Cu} \%$ & $\mathrm{pb} \%$ & $\mathrm{Zn} \%$ & 坑内 $(t$ & ) 全山 $(t$ \\
\hline $\begin{array}{l}32 \text { 年 } \\
33 \\
34 \\
35 \\
36 \\
37 \\
38 \\
39 \\
40 \\
41 \\
\text { 訫均 }\end{array}$ & $\begin{array}{r}86,665 \\
90,615 \\
98,819 \\
135,593 \\
164,898 \\
159,968 \\
180,381 \\
244,524 \\
255,489 \\
265,143 \\
1,682,095 \\
168,210\end{array}$ & $\begin{array}{l}0.77 \\
0.76 \\
0.70 \\
0.56 \\
0.55 \\
0.54\end{array}$ & $\begin{array}{l}2.30 \\
2.19 \\
2.29 \\
2.31 \\
2.31 \\
2.35 \\
1.77 \\
1.30 \\
1.27 \\
1.12\end{array}$ & $\begin{array}{l}4.26 \\
4.07 \\
4.05 \\
3.77 \\
4.07 \\
4.09 \\
3.56 \\
3.26 \\
3.33 \\
3.08\end{array}$ & $\begin{array}{l}52 \\
53 \\
52 \\
55 \\
58 \\
56\end{array}$ & $\begin{array}{l}27 \\
28 \\
30 \\
32 \\
33 \\
34\end{array}$ \\
\hline
\end{tabular}

山

\section{1. 緒言}

位置 : 大泉鉱山は, 山形県東田川郡朝日村大字大鳥字 寿岡にあり, 羽越本線鶴岡駅の南方 $37 \mathrm{~km}$ 点に事務所, 選鉱場がある。山元はさらに $11.3 \mathrm{~km}$ 南に位置している。

沿革 : 明治 12,13 年頃，部落民により発見され明治 23 年浅野総一郎の所有となりその後古河市兵衛の手に移 り，明治 38 年古河鉱業大鳥鉱山と称す。昭和 12 年大日本 鉱業の所有となり選鉣場，索道の設備起業に着手す。昭 和21年選鉱場が焼失したため一時中止，昭和25年日産60 $\mathrm{t}$ の選鉱場が落成した後拡張を重ね現在に至る。

現状：（昭和42年 3 月実績）

第1表 粗鉱量と出鉱量の 第 2 表 開探鉱出鉱量招よ 品位 び試錐延長

\begin{tabular}{|c|c|c|c|c|c|c|c|c|c|}
\hline \multirow{2}{*}{$\begin{array}{c}\text { 粗 錇 量 } \\
(\mathrm{t})\end{array}$} & & 位 & $(\%$ & & \multirow{2}{*}{$\begin{array}{l}\text { 試錐 } \\
\text { 延長 } \\
(\mathrm{m})\end{array}$} & \multirow{2}{*}{$\begin{array}{c}\text { 探鉣 } \\
\text { 延長 } \\
(\mathrm{m})\end{array}$} & \multicolumn{3}{|c|}{ 出触 量 $(\mathrm{t})$} \\
\hline & $\mathrm{Cu}$ & $\mathrm{pb}$ & $\mathrm{Zn}$ & $\overline{\mathrm{s}}$ & & & 開探鉱 & 採鉣 & 柿 \\
\hline $5,257.440$ & 0.17 & & & & 257.1 & 203.5 & 611 & 4,646 & 5,257 \\
\hline
\end{tabular}

第 3 表 従業員（鉱山部一鉱床探查，採掘選鉣部門一）

\begin{tabular}{|c|c|c|c|c|}
\hline 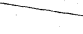 & & 坑 内 & 坑 外 & 訢 \\
\hline $\begin{array}{l}\text { 職 } \\
\text { 従 } \\
\text { 臨 時 }\end{array}$ & $\begin{array}{l}\text { 員 } \\
\text { 業(含請負) } \\
\text { 計 }\end{array}$ & $\begin{array}{r}7 \\
56 \\
25 \\
88\end{array}$ & $\begin{array}{r}26 \\
70 \\
40 \\
136\end{array}$ & $\begin{array}{r}33 \\
126 \\
65 \\
224\end{array}$ \\
\hline
\end{tabular}

\section{2. 地質・鉱 床}

本鉱山付近の地質は基盤を構成する古生層，花崗斑岩

* 大日本鉱業株式会社大泉鉱業所

$1690\langle 108\rangle$
正会員 河 村 忠 男
Tadao KAWAMURA
とこれを不整合に被覆する新第三紀層よりなる。新第三 紀層は下部より踏岩, 砂岩頁岩の互層, 緑色凝灰岩, 変 朽安山岩, 緑色凝灰角碩岩, 凝灰質頁岩等の互層およびこ れらを貫く岩脈状または岩株状の石英粗面岩よりなる。

本地域の鉱床注色凝灰岩, 変朽安山岩, 緑色凝灰角 砂岩中に胚胎する浅熱水性裂力充填鉱床で, 現在稼行中 のものは東西系として大床銿，大銅銿，西の俣銿，南北 系として $314 \mathrm{~m}$ 銿, 新盛銿の 5 脈である。鉱石は主とし て閃覀鉛鉱, 方鉛鉱, 黄鉄鉱, 黄銅鉱, 菱満俺鉱等で, 赤鉄鉱，磁鉄鉱を伴う石英を脈石とする。

第 4 表 鉱床一覧表

\begin{tabular}{|c|c|c|c|c|c|}
\hline 捈脈名 & 走 & 斜 & $\begin{array}{l}\text { 走向延 } \\
\text { 甚 }(\mathrm{m})\end{array}$ & $\begin{array}{l}\text { 脈 幅 } \\
(\mathrm{cm})\end{array}$ & 考 \\
\hline 大滝 銿 & $\mathrm{N} 80^{\circ} \mathrm{W}$ & $70^{\circ} \sim 80^{\circ} \mathrm{N}$ & 500 & - & 採摭 \\
\hline 大床銿 & $\mathrm{N} 70^{\circ} \sim 80^{\circ} \mathrm{W}$ & $70^{\circ} \sim 80^{\circ} \mathrm{N}$ & 2,300 & 40 & \\
\hline 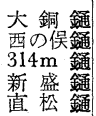 & $\begin{array}{c}\mathrm{EW} \\
\mathrm{N} 30^{\circ} \sim 40^{\circ} \mathrm{W} \\
\mathrm{N} 20^{\circ} \mathrm{E} \\
\mathrm{N} \mathrm{S} \sim \mathrm{N} 20^{\circ} \mathrm{E} \\
\mathrm{N} 40^{\circ} \mathrm{W}\end{array}$ & $\begin{array}{c}70^{\circ} \mathrm{S} \\
50^{\circ} \sim 70^{\circ} \mathrm{W} \\
70^{\circ} \mathrm{W} \\
70^{\circ} \mathrm{W} \\
70^{\circ} \mathrm{W}\end{array}$ & $\begin{array}{l}800 \\
300 \\
600 \\
600 \\
200\end{array}$ & $\begin{array}{r}50 \\
60 \\
50 \\
80 \\
-\end{array}$ & 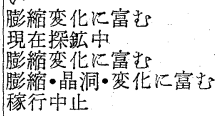 \\
\hline
\end{tabular}

\section{3. 採 掘法}

当山の鉱脈は, 鉣石幅平均 $50 \mathrm{~cm}$ の細脈であり, 母岩 は比較的堅硬であるため，従来よりシニリンケージ採掘 法が採用されてきた。細脈採掘法については種々検討を 加え, 試験的に上向充填採掘法およびストリッピング採 掘法等を試みたが, 鉱脈が概して, 走向傾斜とともに変 化に富み膨縮性大であるためコスト高となり，現在は全 面的にシニリンケージ採掘法を採用している。

採掘準備：採掘鉱画は $30 \mathrm{~m} \times 30 \mathrm{~m}$ を基準としており, 
水平 $30 \mathrm{~m}$ 間の天盤を幅 $1.2 \sim 1.5 \mathrm{~m}$, 高さ $2 \mathrm{~m}$ に落し， 1 $\mathrm{m}$ 分繰置穿孔をし，高さ $2 \mathrm{~m}$ 分の下積運搬をなす。 $1 \mathrm{~m}$ 間隔に支柱を施して $2 \mathrm{~m}$ 置きに漏斗を設けるが，鉱況不 良および上下盤不良などのある場合は竜頭を残すゆえ $2 \sim 4 \mathrm{~m}$ に漏斗 1 個設置する。両端 $1 \mathrm{~m}$ は人道間とする。

穿孔発破：さく岩機はTY-24にXOL-30のフィード をし，上向に穿孔間隔0.4 0.6m，深さ0.9〜1.0mの穿 孔をなす。発破は 3 号桐ダイナマイトおよび硝油爆薬に て電気発破を行なら。

切羽運搬：切羽各漏斗上り横転式鍋鉱車 $\left(0.4 \mathrm{~m}^{3}\right)$ に て，抜鉱された鈗石は， $2 \mathrm{t}$ 電車および手押にて鉱石立 坑に投入する。各立坑にはレールを用いた $20 \mathrm{~cm}$ 間隔の グリズリを設備し, 網上は運搬夫が大割し, ズリ塊は採 掘跡に充塡処理する。

支保：坑道に扔いては上下艋に根掘をなし, 打込張木 を行なつている。状況に応じては片留, 三留などを実施 する。また採掘切羽では盤の悪い所は竜頭を残したり， ルーフボルト，盤押などを実施している。

充填：採掘跡は両盤が比較的堅硬なので早急に充填す る必要はないが，探鉱坑道によるズリを徐々に充填して いる。

第 5 表 採掘法別出釯量および切羽数（昭和 42 年 3 月）

\begin{tabular}{c|c|c|c}
\hline 採搁法の種 類 & 出鉱量 $\mathrm{t}$ & 出鈗比率\% & 切 羽 数 \\
\hline シュシンヶーシ & 4,646 & 100 & 13 \\
\hline
\end{tabular}

\section{4. 運搬}

採掘切羽より拔鉱された鉣石抒よび坑道掘進にてロ一 ダ積または手積により積込まれた鉱石は主要立坑に集め られ，また下部は中央立坑に集荷され，スキップ巻上に て 0 L 貯釷舎に投入され, $2 \mathrm{t}$ 電車にて $1 \mathrm{t}$ 積鉱車に積込 み, $3 \mathrm{t}$ 電車にて坑外に搬出, 山元選鉱場で粗砕し, 手
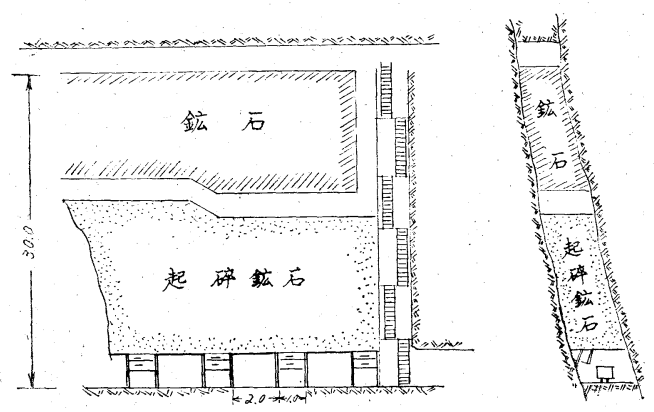

第1図 シニリンケージ法採掘略図
選で廃石を除き索道（距離 $6.7 \mathrm{~km}$ ) によつて 寿岡選鉱 場に送られる。

\section{5. 通 気, 排 水}

通気は自然通気で，各銿各切羽は立坑その他各所専用 人道等で連絡され，上 $8 \mathrm{~L} ，$ 上 $4 \mathrm{~L}$ おび旧大鳥鉱山通 洞玾等 3 個所で坑外に貫通しているので全般的に良好で ある。坑内温度は, $15 \sim 20^{\circ} \mathrm{C}$ である。

排水は下 $3 \mathrm{~L} に 60 \mathrm{PP}$ タービンポンプ 2 台 (予備 1 台) 配置し, 約 $0.5 \mathrm{~m}^{3} / \mathrm{min}$ を揚水し 坑口に㧍ける全排水量 は $2.5 \mathrm{~m}^{3} / \mathrm{min}$ である。

\section{6. 問題点と将来の計画}

大泉に预ける採掘の概要を述べたが，鉱床が広範囲に 分散して打り逐次運搬距離が遠隔化の傾向にあるため, 運搬系統の合理化を最重点に下記の事項に検討を加え， 作業能率の向上に前進する所存である。

1. 切羽運搬の能率化

2. 切羽の集約化

3. 間接工数の減少

第 7 表 過去10年間の年間出鉱量, 平均品位および 能率（坑内, 全山）の推移

\begin{tabular}{|c|c|c|c|c|c|c|}
\hline \multirow{2}{*}{ 年 度 } & \multirow{2}{*}{$\begin{array}{c}\text { 年間出鉱量 } \\
(\mathrm{t})\end{array}$} & \multicolumn{3}{|c|}{ 平 均 品. 位 $(\%)$} & \multicolumn{2}{|c|}{$\begin{array}{c}1 \\
\text { 出人 } \\
\end{array}$ 鉱 } \\
\hline & & $\mathrm{Cu}$ & $\mathrm{Pb}$ & $\mathrm{Zn}$ & 坑内 $(t)$ & 全山( $t$ ) \\
\hline \begin{tabular}{|c|}
32 年 \\
33 \\
34 \\
35 \\
36 \\
37 \\
38 \\
39 \\
40 \\
41 \\
詰均
\end{tabular} & $\begin{array}{r}35,671 \\
37,827 \\
42,623 \\
44,156 \\
47,810 \\
49,151 \\
47,295 \\
52,383 \\
54,027 \\
56,733 \\
467,676 \\
46,768\end{array}$ & $\begin{array}{l}0.53 \\
0.57 \\
0.45 \\
0.32 \\
0.31 \\
0.32 \\
0.19 \\
0.18 \\
0.19 \\
0.24 \\
0.31\end{array}$ & $\begin{array}{l}1.24 \\
1.34 \\
1.61 \\
1.91 \\
1.66 \\
1.85 \\
1.88 \\
1.65 \\
1.62 \\
1.43 \\
1.63\end{array}$ & $\begin{array}{l}5.65 \\
5.22 \\
5.29 \\
5.58 \\
4.91 \\
5.13 \\
5.32 \\
4.62 \\
4.96 \\
4.88 \\
5.12\end{array}$ & $\begin{array}{l}35.7 \\
38.2 \\
43.6 \\
45.7 \\
51.7 \\
55.4 \\
63.1 \\
65.3 \\
59.0 \\
64.3\end{array}$ & $\begin{array}{l}11.2 \\
12.6 \\
14.6 \\
15.9 \\
17.7 \\
19.1 \\
24.3 \\
23.3 \\
23.5 \\
24.8\end{array}$ \\
\hline
\end{tabular}

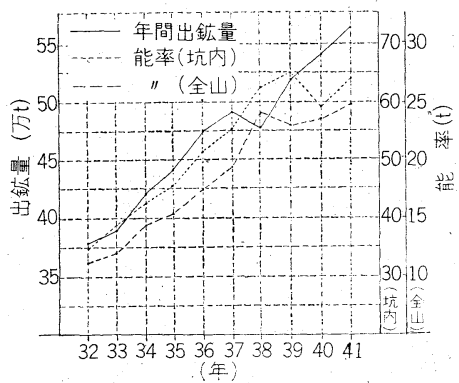

第 2 図

第 6 表 採掘法別工程原単位扣よび直接採掘, 採鉣費 （昭和 42 年 3 月）

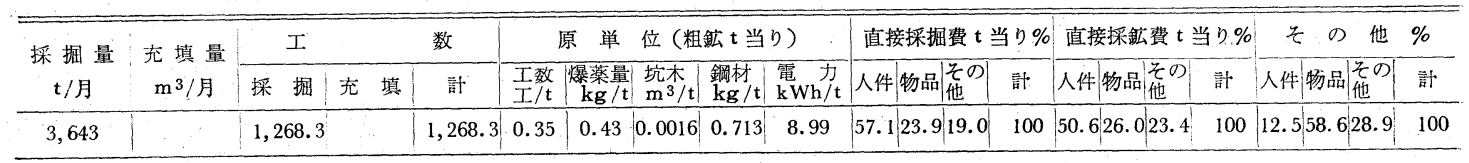

